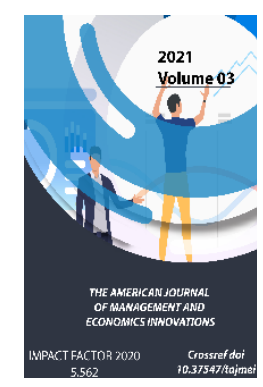

\title{
The Role Of The State In The Innovative Development Of Tourism
}

Journal Website: https://theamericanjou rnals.com/index.php/ta jmei

Copyright: Original content from this work may be used under the terms of the creative commons attributes 4.0 licence.

\section{Oltaev Shavkat Sobirovich \\ Teacher Of Samarkand Institute Of Economics And Service, Candidate Of Economic Sciences, Uzbekistan}

\section{ABSTRACT}

This article examines the need for innovative development of tourism and the role of the state in its implementation, the main areas of state support for innovative activities in tourism.

\section{KEYWORDS}

Tourism, Domestic Tourism, Foreign Tourism, Inbound Tourism, Outbound Tourism, Innovation, Innovation Activity, Government, Digital Economy, E-Commerce.

\section{INTRODUCTION}

One of the priorities of large-scale economic reforms in Uzbekistan within the framework of the Action Strategy is to make tourism one of the leading sectors of the national economy [1].

According to the World Tourism Organization (WTO), tourism in 2017 accounted for $10.2 \%$ of world GDP. At the international level, this sector accounts for $6 \%$ of exports of goods and services, $30 \%$ of total exports of services, and 9.6\% of total employment, and every eleventh new job is created in the world in tourism [2].
In his speech to the Oliy Majlis, President of the Republic of Uzbekistan Sh.M.Mirziyoev highlighted the program and strategic tasks to be implemented in the country in order to ensure economic stability and accelerate its development in 2021 and beyond. [3]. The serious attention paid by the head of state to tourism shows that it is possible to rely on state support and assistance in the implementation of the complex tasks facing it in the future, to attract the necessary resources for the development of the industry, to receive financial and organizational assistance. 


\section{ANALYSIS OF THE RELEVANT LITERATURE}

Many foreign and domestic scientists have conducted research on the socio-economic significance of the development of tourism, theoretical and practical issues of economic relations specific to the industry, practical problems and specific issues in the development of innovative activities in tourism. A. from CIS scientists. Aleksandrova [4], A. Alonko [5], M. Vorontsova [6], I. Markova [7] and others. Issues of development of the tourism industry in our country M.K.Pardaev [8], D.H.Aslanova [9], M.M. Muhammedov [10], N.T.Tukhliev [11], I.S.Tukhliev [12] and others.

\section{ANALYSIS AND RESULTS}

Decree of the President of the Republic of Uzbekistan dated February 3, 2018 "On additional organizational measures to create favorable conditions for the development of tourism potential of the Republic of Uzbekistan" and February 6, 2018 "On measures to develop inbound tourism" The decisions on the measures will be an important organizational and legal program for the rapid development of tourism, rational use of available opportunities, increasing the flow of foreign visitors, demonstration of tourism, cultural, natural and sports potential to the world, in turn, the formation of domestic tourism culture [13].

In order to reveal the essence of the process of state regulation of tourism, it can be interpreted in the form of a diagram.

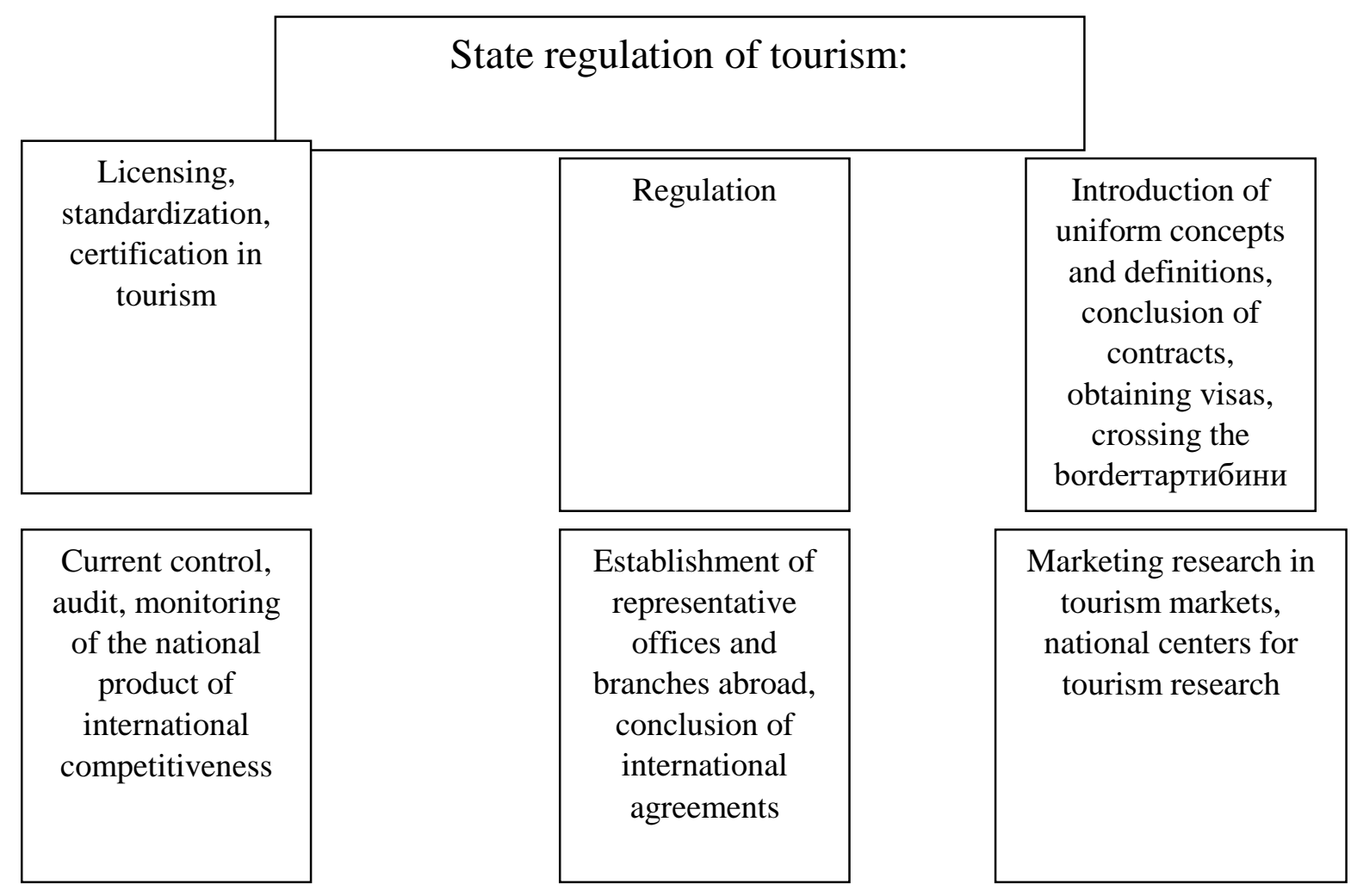

Figure 1. State regulation of tourism [14]. 
The state regulation and support of the tourism sector is carried out in several areas, the main tasks of which should include:

First, the development of the main directions, principles and objectives of state policy in the field of tourism and its development, their implementation and the introduction of mechanisms to control their activities;

Secondly, to create favorable conditions for the development of tourism and the fulfillment of its tasks, to coordinate the activities of various structures, to promote the formation of infrastructure, to protect the environment;

Third, the organization of the provision of enterprises and organizations in the field of tourism with qualified specialists;

Fourth, support by stimulating innovation in tourism, developing marketing, forming a positive image of the country. The development of innovative activities in tourism is a very complex process, which is the most financially difficult, with great risk for the investor. The creation of innovation, its application in practice, its positive effect is possible with the support and assistance of the state, as it requires the joint efforts of various economic and social sectors, combining all opportunities and resources.

\section{CONCLUSIONS AND SUGGESTIONS}

In our opinion, the role of the state in the innovative development of tourism should be realized in several important areas: first, to strengthen the direct participation of the state in the implementation of large special-purpose programs funded from the budget and provided free of charge to all users; secondly, to continue the practice of developing regional targeted programs for the development of tourism in many regions of Uzbekistan, especially in areas with high tourist potential, which are of great importance for attracting tourists;

Third, it is necessary to strengthen control over their implementation; fourth, the development of tourism and transport infrastructure within the framework of such programs, given the current situation; Fifth, serious attention should be paid to improving the quality of public services, providing information resources to the region's tourism and promoting its entry into the world market, conducting scientific and statistical research in tourism, financing the training of qualified personnel to meet the needs of this important industry.

Sixth, one of the important directions of supporting innovative activities of the state in the field of tourism is the establishment of tourist information centers.

\section{REFERENCES}

1. Decree of the President of the Republic of Uzbekistan dated February 7, 2017 No PD-4947 "On the strategy of further development of the Republic of Uzbekistan".

2. Travel \& Tourism Economic Impact 2017 World, [Электрон манба]: http:// www.wttc.org

3. Address of the President of the Republic of Uzbekistan Shavkat Mirziyoyev to the Supreme Council. , [Electronic source]: www.UzA.uz December 29, 2020

4. Alexandrova A.Yu. International tourism. - M .: Aspect Press, 2002.346

p. 
5. Alonso.A.D., Ogle A. (2010). Tourism and hospitality small and medium enterprises and environmental sustainability. Management Research Review, 33.

6. Vorontsova M.G. Tourism: Organization and Management. Textbook. Benefit. - SPb .: SPbGUKI, 2004.

7. Markova I.S. Organizational and economic mechanism for the development of the market of tourist services (on the example of the Khabarovsk Territory) Diss. ... doc. econom. n. Khabarovsk, 2009.

8. Pardaev M.Q. Analysis and evaluation of tourist resources. Samarkand, SIES, 2006. - 137p.

9. Aslanova D.Kh., Zokhidov F.F. Domestic tourism in Uzbekistan: problems and solutions // "Problems of development of the service sector in the context of an innovative and digital economy" Collection of materials of the international scientific and practical conference (IV-part) SIES, 2020, -64 p.

10. Muxammedov M.M., Rakhmatov F. Formation of market relations in the field of tourism and its impact on network efficiency indicators // Service and tourism: management and development problems. Proceedings of the International Conference. Samarkand 2007.

11. Tukhliev N., Abdullaeva T. Management and business organization in tourism in Uzbekistan. $\mathrm{T}$.: State scientific publishing house Y̌zbekiston milliy encyclopediyasi, 2006 -- $367 \mathrm{p}$.

12. Tuxliev I.S., Hayitboev R., Ibodullaev N.E., Amriddinov R.S. Basics of tourism. Textbook. -S :. SamISI, 2010. $-247 \mathrm{p}$.

13. Mirziyoev Sh.M. Decree "On additional organizational measures to create favorable conditions for the development of tourism potential of the Republic of Uzbekistan", as well as the Decree "On measures to develop inbound tourism" dated February 6, "On measures to ensure the accelerated development of domestic tourism." The word of the people. February 6-7, 2018.

14. K.Suyunova. The main directions of state regulation of tourism / / Samarkand State University Scientific Bulletin № 4 (116) 2019. 110-114p. [Electronic source]: http://www.samdu.uz/uzk/ilmiy-jurnal 